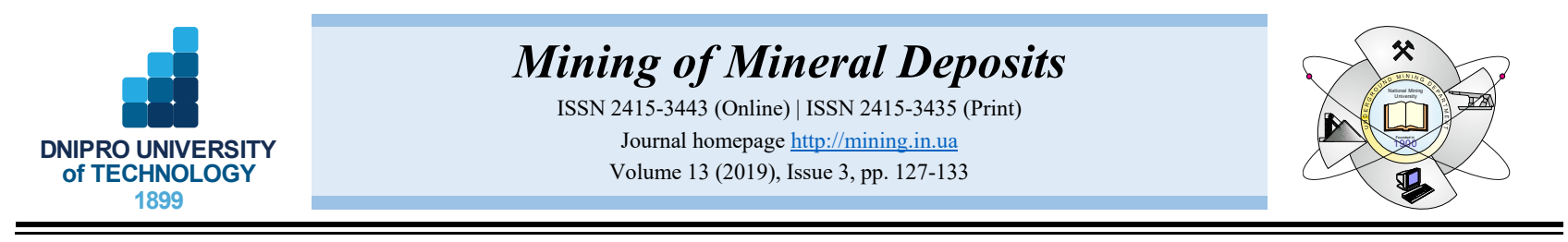

UDC 622.240 .053

https://doi.org/10.33271/mining13.03.127

\title{
PREDICTING REMAINING LIFETIME OF DRILL PIPES BASING UPON THE FATIGUE CRACK KINETICS WITHIN A PRE-CRITICAL PERIOD
}

\author{
V. Tyrlych ${ }^{1 *}$, V. Moisyshyn ${ }^{1}$ \\ ${ }^{1}$ Ivano-Frankivsk National Technical University of Oil and Gas, Ivano-Frankivsk, Ukraine \\ *Corresponding author: e-mail turluch27@ukr.net, tel.+380952176271
}

\begin{abstract}
Purpose is to determine regularities of the development of corrosive fatigue cracks in terms of high-strength drill pipes.

Methods. Basing upon the approaches of the material failure mechanics, the crack has been characterized by the area that is the integral characteristic. Having applied the equivalent area methods, semicircle fatigue crack has been considered instead of the plane fatigue crack of the arbitrary shape; the semicircle fatigue crack is equivalent to the plane fatigue crack of the arbitrary shape in terms of the area. Kinetics of its growth has been analyzed basing on the solution of the first order differential equation which determines dependence of the equivalent semicircle radius upon the number of loading cycles in terms of the specified initial condition. Critical radius dimension has been defined provided that the condition of transition to unstable failure is met within at least one contour point.

Findings. Remaining lifetime of drill pipe TBPV $127 \times 9.19$ S-135 with the detected cross crack of the fixed area has been evaluated; in terms of the specified operating modes, the lifetime was 653000 cycles, i.e. 181 hours. According to the production data, that pipe operated 3215 hours in the well including 200 hours after the last defectoscopy; that correlates with the obtained results.

Originality. The proposed mathematical model of the fatigue crack development makes it possible to calculate the remaining lifetime of drill pipes approximately but sufficiently enough for practical needs.

Practical implications. The obtained regularities may be used to sort out the defected pipes as well as to substantiate periodical non-destruction control in the process of drilling and tripping operations. Studies of the fatigue crack growth may be the basis to develop measures aimed at reducing stresses effecting the drill string and minimizing washout formations; that will help prolong the drill pipe life.
\end{abstract}

Keywords: drill pipe, crack, stress intensity coefficient, kinetics, loading cycle, remaining lifetime

\section{INTRODUCTION}

\subsection{Statement of the problem}

Practice of drilling oil and gas wells shows that fatigue and corrosive-fatigue damages are the most often reasons for the failures of drill string elements (MacDonald, 1994; Dzheyson, Reynol'ds, Ellis, \& Styuart, 2004; Artym, Yatsynyak, Hrytsiv, Yurych, \& Rachkevych, 2012; Zamani, Hassanzadeh-Tabrizi, \& Sharifi, 2016).

Table 1 represents the data concerning failures of drill pipes in terms of well drilling within the area of Ukrburgas drilling division (DD) in 2015-2017. The mentioned period demonstrates 75 failure cases in terms of pipe body and 2 failures in terms of threaded joints. Main reasons of the first failure type are as follows: formation of micro-cracks with their further erosion and fatiguerelated complete breaking (44 cases); fatigue breaking due to the effect of considerable sign-reversing loads
(19 cases). Other accidents occurred due to the nonobservance of technological processes during trips and as a result of bit overloading or jamming.

Pipes were most often damaged within the range of $0.5-0.6 \mathrm{~m}$ from the face of coupling or nipple (27 cases); in general, the failures were recorded at the distance of $1 \mathrm{~m}$ from a coupling (38 cases) or nipple (37 cases).

The damaged pipes operated in the holes during different periods of time: $17.2 \%$ of pipes operated up to 4000 hours; $26.7 \%$ - from 4000 to 8000 hours; $18.7 \%$ from 8000 up to 12000 hours; $26.7 \%$ - from 12000 up to 14000 hours; and $10.7 \%$ - more than 14000 hours. After defectoscopy, the pipes operated from 30 to 380 hours more. That indicates the fact that the pipes operating in the well had certain mechanical damages being the stress concentrators and reducing operating period of drill pipes. Bottom of those failures contains a layer of plastically deformed (during the failure formation) metal.

(C) 2019. V. Tyrlych, V. Moisyshyn. Published by the Dnipro University of Technology on behalf of Mining of Mineral Deposits.

This is an Open Access article distributed under the terms of the Creative Commons Attribution License (http://creativecommons.org/licenses/by/4.0/),

which permits unrestricted reuse, distribution, and reproduction in any medium, provided the original work is properly cited. 
Table 1. Data concerning drill string failure occurring while drilling wells within the areas of Ukrburgas DD in $2015-2017$

\begin{tabular}{|c|c|c|c|c|}
\hline & \multicolumn{3}{|c|}{$\begin{array}{c}\text { Year } \\
\text { (number of accidents) }\end{array}$} & \multirow{2}{*}{$\begin{array}{c}\text { Total } \\
\text { number }\end{array}$} \\
\hline & $\begin{array}{l}2015 \\
(29)\end{array}$ & $\begin{array}{c}2016 \\
(18)\end{array}$ & $\begin{array}{l}2017 \\
(28)\end{array}$ & \\
\hline \multicolumn{5}{|l|}{ Failure point } \\
\hline From coupling face & 12 & 10 & 16 & $38(50,7)$ \\
\hline From nipple face & 17 & 8 & 12 & $37(49,3)$ \\
\hline $\begin{array}{l}\text { Reason of pipe } \\
\text { failure }\end{array}$ & & & & \\
\hline $\begin{array}{l}\text { Formation of micro- } \\
\text { cracks with their fast } \\
\text { erosion and further } \\
\text { pipe parting }\end{array}$ & 23 & 6 & 15 & $44(58,7)$ \\
\hline $\begin{array}{l}\text { Fatigue metal failure } \\
\text { due to considerable } \\
\text { sign-reversing loads }\end{array}$ & 1 & 7 & 11 & $19(25,3)$ \\
\hline Other reasons & 5 & 5 & 2 & $12(16)$ \\
\hline $\begin{array}{l}\text { Type of the } \\
\text { damaged pipe }\end{array}$ & & & & \\
\hline $\begin{array}{l}\text { TBPK } 127 \times 9,19 \\
\text { G-105, S- } 135 \text {, class } 1\end{array}$ & 4 & 5 & 6 & $15(20)$ \\
\hline $\begin{array}{l}\text { TBPK } 127 \times 9,19 \\
\text { G-105, S- } 135 \text {, class } 2\end{array}$ & 9 & 7 & 8 & $24(32)$ \\
\hline $\begin{array}{l}\text { TBPK } 127 \times 9,19 \\
\text { G-105, S-135, class } 3 \\
\text { Number of } \\
\text { operating hours }\end{array}$ & 16 & 6 & 14 & $36(48)$ \\
\hline $0-4000$ & 5 & 4 & 4 & $13(17,2)$ \\
\hline $4000-8000$ & 8 & 2 & 10 & $20(26,7)$ \\
\hline $8000-12000$ & 3 & 5 & 6 & $14(18,7)$ \\
\hline $12000-14000$ & 9 & 5 & 6 & $20(26,7)$ \\
\hline$>14000$ & 4 & 2 & 6 & $8(10,7)$ \\
\hline
\end{tabular}

That layer may contain micro-ruptures resulting in the origin and progress of fatigue cracks during the operation. Growth of the cracks depends upon their dimension, direction, and nature of operational loads in the process of drilling and tripping.

Taking into consideration the abovementioned facts, it may be concluded that fatigue failure of a drill string is still the dominating breakdown reason while drilling.

\subsection{Analysis of literature sources}

Numerous papers by both national and foreign researchers deal with the problems of determining lifetime for drill string elements. Authors of papers (Kryzhanovskii, 1978; Pokhmurskii, Kryzhanovskii, Ivasiv, Poddubnyi, \& Yanyshivskii, 1984; Kryzhanovskii, 1991; Kryzhanivs'kyi, Tsyrul'nyk, \& Petryna, 1999) propose using curves of fatigue and curves of corrosive fatigue which are usually described by equation:

$\lg \left(\sigma_{a}\right)_{n}=b \cdot \lg N+a$,

where:

$\left(\sigma_{a}\right)_{n}$ - the amplitude stresses of an asymmetric cycle reduced to a symmetric cycle;

$a, b$ - the parameters of the equation determined in terms of the given non-destruction probability on the basis of fatigue tests of the sampling of full-scale drill string elements;
$N$ - the number of cycles up to the failure of a drill string element.

To predict endurance of drill string elements basing upon the results of studying their current state, authors of papers (Ivasiv, Artym, Hrytsiv, \& Rachkevych, 2010; Kryzhanivs'kyy \& Kopey, 2010) propose to apply $G$ criterion. Ratio of fatigue area to nominal area of weak pipe section is used as the failure degree while bending. Failure degree $G$ is the growing linear function depending upon the number of loadings; it varies within the range from 0 to 1 . It has following form:

$G=G_{0}-\left(G_{0}-G_{k}\right) \frac{N_{T}}{N}$,

where:

$G=|\lg (D)|-$ the current value of the criterion;

$G_{0}=\left|\lg \left(D_{0}\right)\right|-$ the value of the criterion at the initial registration moment;

$G_{k}=\left|\lg \left(D_{k}\right)\right|-$ the value of the criterion at the moment of failure;

$N_{T}$ - the current number of loading cycles;

$N$ - the number of loading cycles before failure.

Another approach to the problem solution is based on the failure mechanics (Migal', Kopey, Karpash, \& Kirindas, 1980; Hnyp, Babyuk, \& Chernov, 1990; Kryzhanivs'kyy, Shats'kyy, \& Petryna, 1997). Following idea is taken as the basis: endurance of a specific drill string element in stipulated by the number of loading cycles $N$ during which crack dimensions grow from the initial $l_{0}$ up to certain critical $l_{C}$ value:

$N=\int_{l_{0}}^{l_{C}} \frac{d l}{V}$,

where:

$V$ - the rate of fatigue crack propagation.

Thus, endurance of the damaged drill string elements is calculated with the help of the crack propagation rate determined by the state of pre-failure zone being described by a stress intensity coefficient (SEC) $K$ (or by the range of a stress intensity coefficient $\Delta K$ ). Practically, graphic dependences $V$ upon $K$ or $\Delta K$ are used which are usually called kinetic diagrams of fatigue failure (KDFF) or diagrams of the material crack-resistance.

The mentioned papers contain formulas to calculate a stress intensity coefficient (or range of stress intensity coefficient) which have different variants of representation depending upon the shape of the fatigue crack front and the selected mathematical model.

Paper (Kryzhanivs'kyy, Shats'kyy, \& Petryna, 1997) represents the data on studies dealing with fatigue endurance of drill pipes; the data are based on the model of semielliptic fatigue crack within a hollow cylinder. The equation describing kinetics of its development is based on the idea on the crack opening in terms of local plane elastoplastic deformation.

Paper (Vaisberg, Vincke, Perrin, Sarda, \& Fay, 2002) describes in detail a cycle of formation and deformation of a fatigue micro-crack. It may be divided hypothetically into three stages (Fig. 1). 


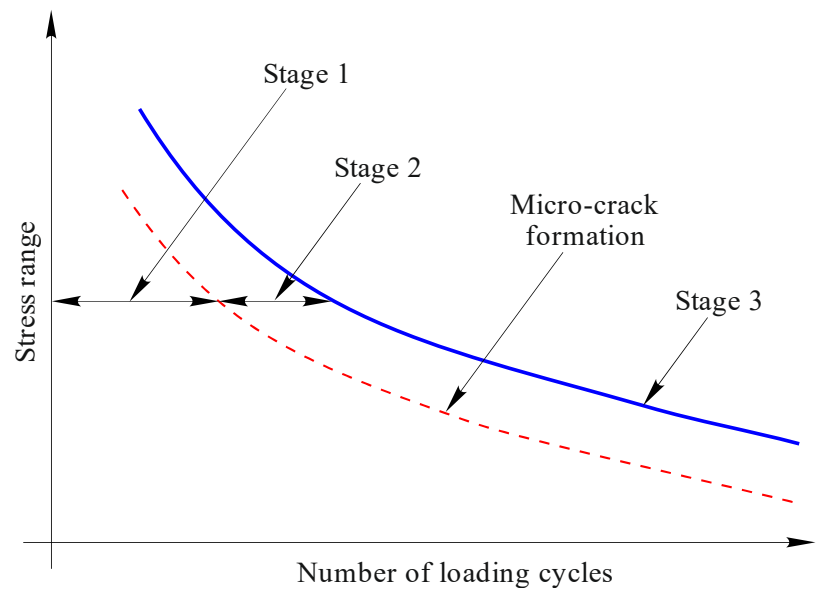

Figure 1. Stages of micro-crack development

Stage 1. During the drill pipe rotation, micro-cracks are being formed on the drill pipe surface near the stress concentrators under the effect of cyclic sign-reversing loading.

Stage 2. Micro-cracks propagate within the pipe body perpendicular to the direction of the effective stress; rate of the micro-crack propagation correlates with its magnitude. Rate of the micro-crack development grows within the areas of stress concentration: threaded joints, points of transfers from a tool joint to a drill pipe body, sections of drill pipe gripping by slips and wrenches, internal surfaces of a drill pipe affected by the pit corrosion (MacDonald, 1994; Macdonald \& Bjune, 2007; Fangpo, Yonggang, Xinhu, \& Caihong, 2011).

Moreover, rate of the micro-crack development is effected by the operating environment (Pokhmurskii, Kryzhanovskii, Ivasiv, Poddubnyi, \& Yanyshivskii, 1984; Zamani, Hassanzadeh-Tabrizi, \& Sharifi, 2016), i.e. drill mud. During the rotation within the curved well shaft, a micro-crack in a drill pipe opens and closes in turn while passing along short and long radius. When it opens, vacuum is formed in a micro-crack acting as the pump to suck in the fluid from the operating environment. After the semi-rotation, a micro-crack closes and the fluid stays inside under pressure resulting in additional breaking effect, so-called wedging effect.

Stage 3. Micro-cracks propagate inward the pipe body resulting in its failure. When the crack depth reaches the pipe side thickness, the opening is formed; flow of drill mud goes through that opening under the pressure and that flow washes out the pipe body causing its complete failure.

Author of paper (Ustalostnoye razrusheniye..., 2018) represent the results of analytic study of fatigue failure of drill pipes during the well construction, the failure prediction and measures to prevent erosion, and failure of the pipes.

\subsection{Statement of the problem}

Problem to control corrosive-fatigue failure of the drill string elements is rather topical. Pipes in the well operate in terms of huge amount of loading cycles resulting in origin and growth of cracks either in the pipe body or at the points of stress concentration (thread, fillet, grooves etc.). At the same time, some cracks are not dangerous from the viewpoint of possible sudden breakdown and pipe can operate with such defects for some time. Consequently, there is a necessity to evaluate the pipe lifetime (both new and the ones with operating defects like fatigue cracks) before the critical situation taking into consideration possible dispersion of fatigue characteristics of the pipe material.

Thus, objective of the study is to determine regularities of the development of corrosive fatigue cracks in terms of high-strength drill pipes.

\section{RESEARCH METHODOLOGY}

To solve the specified problem, use the approaches of failure mechanics. Basing upon analysis of the drill string loading conditions and possible reasons of drill string elements failure by non-destructive methods, find the crack-type defect. It is characterized by area $S_{0}$ being the integral characteristic. A crack is within the plane perpendicular to the effective load (well axis), i.e. stressstrain state is symmetric relative to the crack plane. The area is of semielliptic shape with semi-axes $2 a$ (length along the circle) and $l$ (depth along the pipe body) or close to it. After that, determine stress-strain state (SSS) within the considered cross section.

Knowing SSS, it is necessary to study failure kinetics, i.e. regularities of the defect development which can be the basis to determine remaining lifetime of the pipe. To analyze kinetics of the crack growth in a pipe, assume the following:

- conditions of automodeling is implemented around the crack top, and stress-strain state within the pre-failure zone is determined only by KDFF;

- crack propagates towards the normal to its surface at any contour point.

Thus, our task is to define dependence of crack area $S$ upon the number of loading cycles $N$ in terms of the initial condition $S(0)=S_{0}$.

Select origin of coordinates in the crack center (Fig. 2). In general case (in terms of complex SSS), a crack will propagate along the curvilinear trajectory which equations in polar coordinate system are as follows $\rho=\rho(N, \varphi), \varphi=\varphi(N)$.

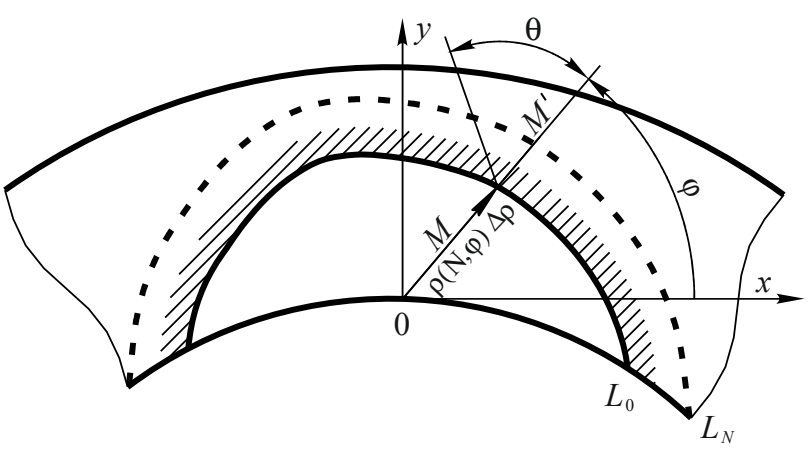

Figure 2. Propagation of the crack front within the drill pipe body

Use equations (Panasyuk, 1988; Andreykiv \& Darchuk, 1992) for a fatigue crack developing within one plane:

$\frac{\partial \rho}{\partial N}\left[1+\frac{1}{\rho^{2}}\left(\frac{\partial \rho}{\partial \phi}\right)^{2}\right]^{-\frac{1}{2}}=v\left(K_{I}\right)$, 


$$
\rho(0, \phi)=\rho_{0}(\phi),
$$

where:

$v\left(K_{I}\right)$ - the dependence of the fatigue crack rate (FCR) upon maximum KDFF value per cycle being determined by kinetic diagram of fatigue crack (KDFC) of the drill pipe material in terms of the specifies loading conditions; $\rho(N, \varphi)$ - the required radius-vector of the moving crack contour in the polar coordinate system;

$\rho_{0}(\varphi)$ - the radius-vector of the initial crack.

Taking into account that:

$$
S(N)=\frac{1}{2} \int_{0}^{2 \pi} \rho^{2}(N, \phi) d \phi,
$$

differentiate expression (5) in terms of $d N$ and get:

$$
\frac{d S}{d N}=\int_{0}^{2 \pi} \rho(N, \phi) \frac{\partial \rho}{\partial N} d \phi
$$

Taking into consideration (4), we will have:

$$
\frac{d S}{d N}=\int_{0}^{2 \pi} \rho \sqrt{1+\frac{1}{\rho^{2}}\left(\frac{\partial \rho}{\partial \phi}\right)^{2}} v\left(K_{I}\right) d \phi .
$$

Having defined that $d t=\sqrt{\rho^{2}+\left(\frac{\partial \rho}{\partial \phi}\right)^{2}} d \phi$ is the element of the crack contour arc, rewrite (7) as follows:

$$
\frac{d S}{d N}=\int_{L} v\left(K_{I}\right) d t .
$$

It is difficult to integrate the expression in the right part (8) since the formulas to find $v\left(K_{I}\right)$ are of complex form and depend upon geometric parameters of the crack contour. In practice, cracks usually have complex configurations; in general, fatigue propagation of such a crack is described by non-linear differential equation with partial derivatives. Nowadays, methods to solve such nonlinear equations have not been developed yet. However, approximate method - equivalent area method proposed in monographs (Panasyuk, 1988; Andreykiv \& Darchuk, 1992) - helps simplify the situation considerably (as a rule, with minor errors).

The essence of the method is based on the assumption that to describe kinetics of the growth of a plane fatigue crack of arbitrary configuration, it is enough to study kinetics of the growth of a circular fatigue crack being equivalent to it in terms of the area.

Introduce parameter $a_{e q}(N)$ - radius of the "equivalent" semi-circle which area is equal to the crack area (Fig. 3) - near value $S(N)$, i.e.:

$$
\frac{\pi \cdot a_{e q}^{2}(N)}{2}=S(N) \text {, }
$$

Then, differential equation (8) will be rewritten as follows:

$$
\frac{d a_{e q}}{d N}=\frac{1}{\pi a_{e q}} \int v\left(K_{I}\right) d t .
$$

(a)

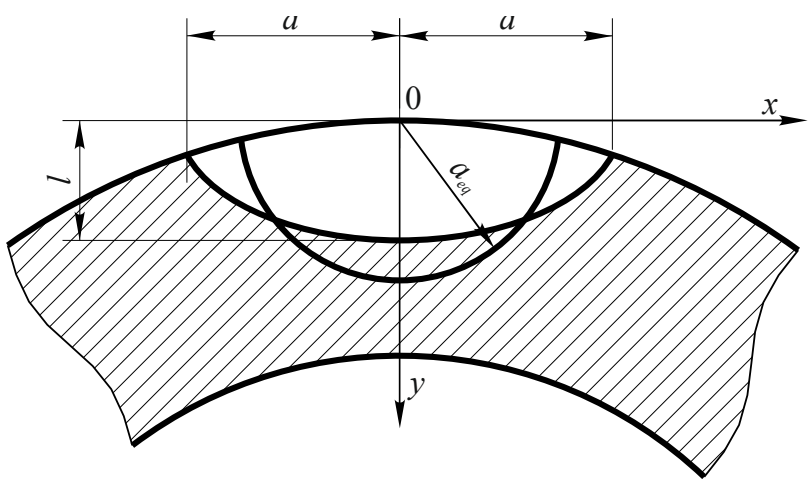

(b)

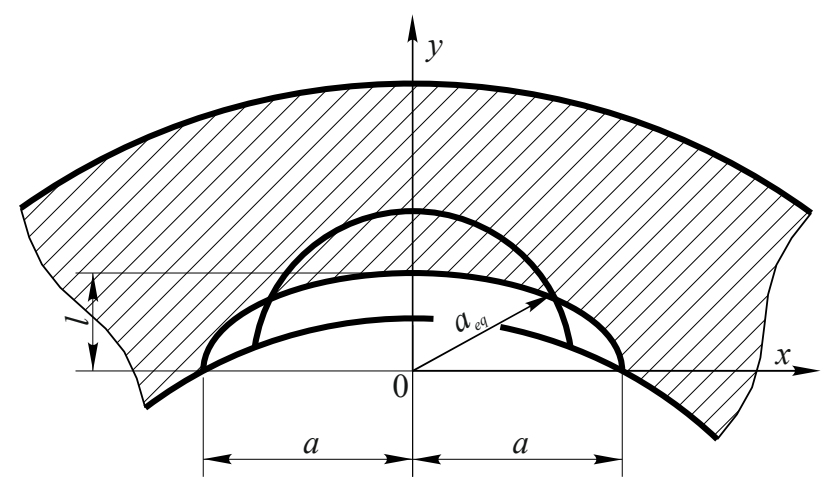

Figure 3. Edge semielliptic crack located on the internal (a) and external (b) surfaces of a drill pipe

Consider that function $v\left(K_{I}\right)$ is continuous and limited within all the points of crack contour; then the latter expression will be of following form:

$\frac{d a_{e q}}{d N}=v\left(K_{\text {Ieq }}\right)$.

Applying Paris formula $v=C \cdot K_{I}^{n}$, value $K_{\text {Ieq }}$ may be represented as:

$K_{\text {Ieq }}=\left[\frac{1}{\pi a_{e q}} \int v\left(K_{I}\right) d t\right]^{\frac{1}{n}}$.

Thus, $K_{\text {Ieq }}$ is the generalized SSS characteristic in the neighbourhood of the developing crack top; it has the specified area $S$ and takes into consideration KDFF changes along its contour.

Move on to the next problem:

$\frac{d a_{e q}}{d N}=v\left(K_{\text {Ieq }}\right), a_{e q}(0)=\sqrt{\frac{S_{0}}{\pi}}$.

Ratio (13) describes approximately kinetics of the growth of the fatigue crack developing within one plane in the invariant form not depending on the defect shape. Value $K_{\text {Ieq }}$ depends insignificantly on the crack configuration and is determined mostly by its area.

According to the studies of pipes disruption, the crack is mostly of semielliptic (or close to it) shape. KDFF for the edge semielliptic crack is determined using following dependence: 
$K_{\text {Ieq }}=\frac{2}{\sqrt{\pi}} \cdot \sigma \cdot \sqrt{a_{e q}} \cdot f\left(\frac{b}{a}\right)$,

where:

$$
f\left(\frac{b}{a}\right) \text { - the complex function of the parameters of }
$$

ellipsis and angle $\beta$. It is close to the constant being taken as 1.1 (Andreykiv \& Darchuk, 1992).

In terms of the edge effect, value $K_{\text {Ieq }}$ depends slightly on the ellipsis semi-axes ratio; thus, we take:

$K_{\text {Ieq }}=1.24 \cdot \sigma \cdot \sqrt{a_{e q}}$.

Taking into account (15), rewrite problem (13) as follows:

$$
\begin{gathered}
\frac{d a_{e q}}{d N}=C \cdot\left(1.24 \cdot \sigma \cdot \sqrt{a_{e q}}\right)^{n}, \\
a_{e q}(0)=\sqrt{\frac{S_{0}}{\pi}},
\end{gathered}
$$

where:

$\sigma-$ the tensile stresses within the crack plane.

Ratio (16) describes approximately growth kinetics of the fatigue cracks which shape is close to a semielliptic crack developing within one plane of a drill pipe.

Having integrated (16), we obtain:

$$
\begin{aligned}
& \frac{d a_{e q}}{d N}=C \cdot\left(1.24 \cdot \sigma \cdot \sqrt{a_{e q}}\right)^{n} a_{e q}(N)= \\
& =\left[\left(a_{e q}\right)^{1-\frac{n}{2}}-\left(\frac{n}{2}-1\right) \cdot C \cdot(1.24 \cdot \sigma)^{n} \cdot N\right]^{\frac{2}{n-2}} .
\end{aligned}
$$

Dependence (17) helps determine radius of the equivalent semi-circle in $N$ cycles which area will be:

$$
S(N)=\frac{\pi \cdot a_{e q}^{2}(N)}{2} .
$$

Critical dimension $a_{e q}^{*}$ is determined basing upon the fact that condition of transition to unstable failure is met within at least one point of the contour:

$K_{\text {Ieq }}=K_{f_{c}}$,

i.e. a crack loses its stability, and its spontaneous growth begins (stage 3 of the fatigue crack development).

Period of the development of initial area crack $S_{0}\left(a^{*}{ }_{e q}\right)$ up to the critical dimension with corresponding value $S^{*}\left(a^{*}{ }_{e q}\right)$ is determined according to formula:

$$
N^{*}=\int_{a_{e q}^{0}}^{a_{e q}^{*}} \frac{d a_{e q}}{v\left(K_{I e q}\right)} .
$$

\section{PRACTICAL CALCULATIONS}

To perform the calculations, drill string of Perekopivska \#63 well was analyzed. In October 2014, there was an accident in this well. There was a parting of drill pipe TBPV $127 \times 9.19 \mathrm{~S}-135$ at the depth of $2775 \mathrm{~m}$. Cross section was represented by the even pipe failure with minor washout traces of $3-4 \mathrm{~cm}$ length around the circle. The failure was caused by the crack formation with further washing out and parting of the drill pipe. Using the proposed model, we have studied the growth kinetics of that fatigue crack.

We analyzed the drill string consisting of two sections: drill pipes TBTV $127 \times 9.19$ S-135 with the length of $4727 \mathrm{~m}$ and heavy-weight drill pipes OBT $165 \times 70$ with the length of $146 \mathrm{~m}$. Operating parameters were as follows: bit loading varied within the range of $G=6-8 \mathrm{t}$, washing liquid loss was $Q=24 \mathrm{l} / \mathrm{s}$, pressure was $P=10 \mathrm{MPa}$, and drill string rotation frequency was $N=50-70 \mathrm{rot} / \mathrm{min}$. Drill mud was of $\rho=1.18 \mathrm{~g} / \mathrm{cm}^{3}$ density and $T=60 \mathrm{~s}$ viscosity.

There was a cross section at the depth of $2775 \mathrm{~m}$; the cross section contained a cross crack within the drill pipe body. The crack shape was close to semielliptic and characterized by cross section area $S_{0}$. Calculations were performed for different values $a_{e q}(0)$ of the "equivalent" semicircle radius which area was equal to the crack area.

In terms of the cross section, there were tensile and bending stresses; oscillation processes occurring within the drill string while hole drilling were taken into account as well. In terms of the specified operating modes of the drill string, stresses varied within the range from $\sigma_{\min }=90 \mathrm{MPa}$ up to $\sigma_{\max }=250 \mathrm{MPa}$.

Calculations were performed for drill pipes $127 \times 9.19$ S-135 with following crack-stability characteristics:

$-n=3.45$

$-K_{f c}=142.8 \mathrm{MPa} \cdot \sqrt{\mathrm{m}}$;

$-C=4.45 \cdot 10^{-12} \mathrm{~m} /(\mathrm{MPa} \cdot \sqrt{\mathrm{m}})^{n}$.

Figure 4 demonstrates the calculation results.

(a)

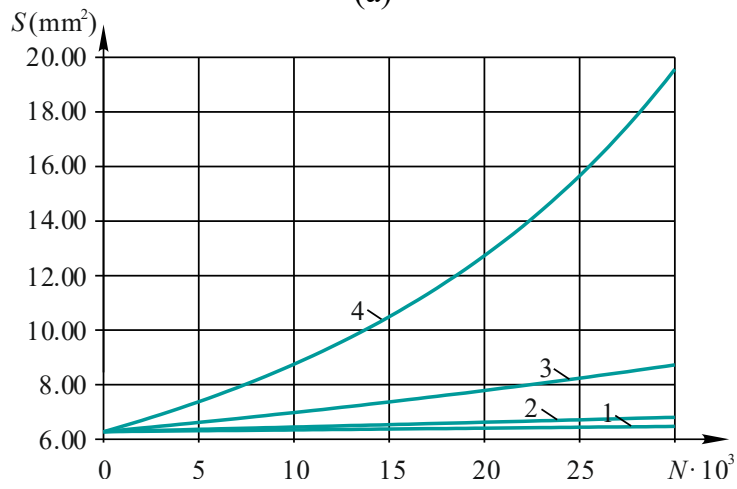

(b)

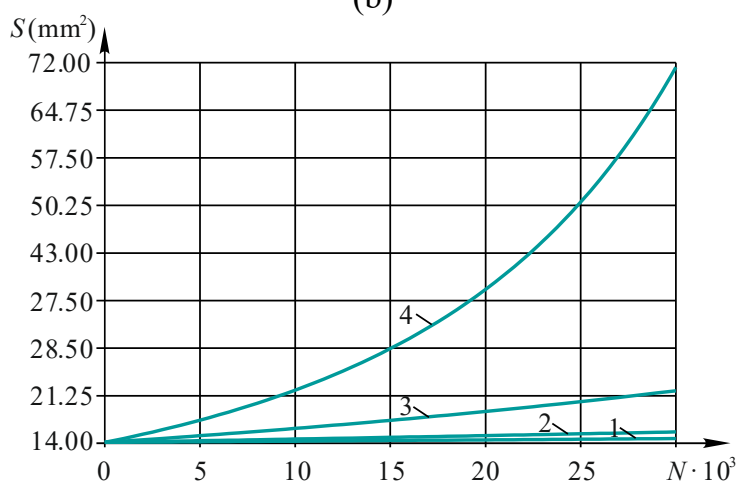

Figure 4. Kinetics of the fatigue crack growth in a drill pipe depending on the effective load: (a) $a_{e q}=2 \mathrm{~mm}$; (b) $a_{e q}=3 \mathrm{~mm} ; 1-90 \mathrm{MPa} ; 2-120 \mathrm{MPa} ; 3-180 \mathrm{MPa}$; 4-250 MPa 
Analysis of the results shows that in terms of the specified operating modes, the crack does not reach critical dimensions, and the pipe may operate within the well for some time more. As soon as the "equivalent" semicircle radius reaches its critical value $a_{e q}^{*}=5.6 \mathrm{~mm}$ for the conditions under consideration), critical crack growth begins resulting in the pipe failure. According to the calculations, pipe with the crack should operate 653000 cycles more, i.e. 181 hours. According to the production data, that pipe operated 3215 hours in the well including 200 hours after the last defectoscopy; it correlates with the obtained results.

\section{CONCLUSIONS}

The proposed mathematical model of the fatigue surface crack development helps calculate the drill pipe lifetime to the extent being rather sufficient for practical implementation. The obtained results may be used to sort out the damaged pipes as well as to substantiate periodical non-destruction control while drilling and tripping.

Analysis of the process of the fatigue crack growth makes it possible to develop measures for reducing stresses effecting the drill string and to minimize formation of openings which help prolong the drill pipe life.

\section{ACKNOWLEDGEMENTS}

The research results are obtained without any support in the form of grants or projects. The authors express their gratitude to the Academician of the National Academy of Sciences of Ukraine, Professor Ye.I. Kryzhanivskyi for his specialized consultations and discussions of the research result.

\section{REFERENCES}

Andreykiv, A.Ye., \& Darchuk, A.I. (1992). Ustalostnoye razrusheniye i dolgovechnost' konstruktsiy. Kyiv: Naukova dumka.

Artym, V.I., Yatsynyak, I.I., Hrytsiv, V.V., Yurych, A.R., \& Rachkevych, R.V. (2012) Analiz koroziyno-vtomnykh ruynuvan' elementiv buryl'noyi kolony. Rozvidka ta Rozrobka Naftovykh i Hazovykh Rodovyshch, 2(43), 197-200.

Dzheyson, K., Reynol'ds, N., Ellis, S.H., \& Styuart, D. (2004). Dostizheniya v proyektirovanii buril'noy kolonny s uchetom ustalostnogo iznosa: teoriya koeffitsiyenta krivizny i illyustrativnyy primer. Neftegazovyye Tekhnologii, (3), 16-18.

Fangpo, L., Yonggang, L., Xinhu, W., \& Caihong, L. (2011). Failure analysis of $\varnothing 127 \mathrm{~mm}$ IEU G105 drill pipe wash out. Engineering Failure Analysis, 18(7), 1867-1872. https://doi.org/10.1016/j.engfailanal.2011.06.018
Hnyp, I.P., Babyuk, I.S., \& Chernov, B.O. (1990). Optymizatsiia dovhovichnosti zamkovykh rizbovykh ziednan burylnoi kolony na osnovi kryteriyiv mekhaniky ruynuvannya. Fiziko-Khimicheskaya Mekhanika Materialov, (6), 105-109.

Ivasiv, V.M., Artym, V.I., Hrytsiv, V.V., \& Rachkevych, R.V. (2010). Udoskonalennya metodyky otsinky dovhovichnosti buryl'nykh trub $\mathrm{z}$ urakhuvannyam ekspluatatsiynykh navantazhen'. Naukovyy Visnyk IFNTUNH, 2(24), 41-45.

Kryzhanivs'kyi, E.I., Tsyrul'nyk, O.T., \& Petryna, D.Y. (1999). Effect of hydrogenation and plastic predeformation of steel on its crack resistance. Materials Science, 35(5), 674-677. https://doi.org/10.1007/bf02359354

Kryzhanivs'kyy, Ye.I., \& Kopey, B.V. (2010). Prohnozuvannya resursu buryl'noyi kolony za parametramy koroziynoyi vtomy ta shvydkistyu poshyrennya vtomnykh trishchyn. Fizyko-Khimichna Mekhanika Materialiv, 409-426.

Kryzhanivs'kyy, Ye.I., Shats'kyy, I.P., \& Petryna, D.Yu. (1997). Otsinka dovhovichnosti burylnykh trub z pozytsiy modeli. Rozvidka $i$ Rozrobka Naftovykh $i$ Hazovykh Rodovyshch, (34), 3-8.

Kryzhanovskii, E.I. (1978). Effect of the drilling solution on the endurance of locking joints. Soviet Materials Science, 13(3), 320-321. https://doi.org/10.1007/bf00716130

Kryzhanovskii, E.I. (1991). Effect of cycle asymmetry on the corrosion fatigue resistance of joints in drilling pipes. Soviet Materials Science, 26(4), 456-459. https://doi.org/10.1007/bf00727063

MacDonald, K.A. (1994). Failure analysis of drillstring and bottom hole assembly components. Engineering Failure Analysis, 1(2), 91-117. https://doi.org/10.1016/1350-6307(94)90010-8

Macdonald, K.A., \& Bjune, J.V. (2007). Failure analysis of drillstrings. Engineering Failure Analysis, 14(8), 1641-1666. https://doi.org/10.1016/j.engfailanal.2006.11.073

Migal', I.G., Kopey, B.V., Karpash, O.M., \& Kirindas, A.V. (1980). Rasprostraneniye korrozionno-ustalostnykh treshchin v buril'nykh trubakh TBVK. RNTS VNIIOENG, Seriya Mashiny i Neftyanoye Oborudovaniye, (9), 10-13.

Panasyuk, V.V. (1988). Mekhanika razrusheniya i prochnost' materialov. Kyiv: Naukova dumka.

Pokhmurskii, V.I., Kryzhanovskii, E.I., Ivasiv, V.M., Poddubnyi, E.V., \& Yanyshivskii, M.Y. (1984). A method of calculating the life of drill pipe joints on the basis of corrosion fatigue tests. Soviet Materials Science, 20(2), 193-195. https://doi.org/10.1007/bf00721353

Ustalostnoye razrusheniye buril'nikh trub, yego prognozirovaniye i profilaktika. (2018). ROGTEC, (52), 62-79.

Vaisberg, O., Vincke, O., Perrin, G., Sarda, J.P., \& Fay, J.B. (2002). Fatigue of drillstring: State of the art. Oil \& Gas Science and Technology, 57(1), 7-37. https://doi.org/10.2516/ogst:2002002

Zamani, S.M., Hassanzadeh-Tabrizi, S.A., \& Sharifi, H. (2016). Failure analysis of drill pipe: A review. Engineering Failure Analysis, (59), 605-623.

https://doi.org/10.1016/j.engfailanal.2015.10.012

\section{ПРОГНОЗУВАННЯ ЗАЛИШКОВОГО РЕСУРСУ БУРИЛЬНИХ ТРУБ ЗА КІНЕТИКОЮ ВТОМНОЇ ТРІЩИНИ В ДОКРИТИЧНИЙ ПЕРІОД}

\section{В. Тирлич, В. Мойсишин}

Мета. Визначення закономірностей розвитку тріщин корозійної втоми у високоміцних бурильних трубах.

Методика. На основі підходів механіки руйнування матеріалів тріщину охарактеризовано площею, яка $\epsilon$ інтегральною характеристикою. Скориставшись методом еквівалентних площ, замість плоскої втомної тріщини довільної конфігурації розглянуто еквіваленту їй за площею напівкругову втомну тріщину. Досліджено кінетику iii росту на основі розв'язку диференціального рівняння першого порядку, який визначає залежність радіуса еквівалентного півкола від числа циклів навантаження за заданої початкової умови. Критичний розмір радіусу визначено з умови того, що хоча б в одній точці контуру досягається умова переходу до нестабільного руйнування. 
Результати. Оцінено залишковий ресурс бурильної труби ТБПВ 127×9,19 S-135 з виявленою поперечною тріщиною фіксованої площі, який при заданих режимах роботи склав 653000 циклів, тобто 181 годину. За промисловим даними ця труба відпрацювала в свердловині 3215 годин, в тому числі 200 годин після останньої дефектоскопії, що корелює з отриманим результатом.

Наукова новизна. Запропонована математична модель розвитку втомної тріщини дає змогу наближено, 3 достатньою для практики точністю, розраховувати залишковий ресурс бурильних труб.

Практична значимість. Одержані закономірності можуть бути використані для відбракування пошкоджених труб, а також для обгрунтування проведення періодичного неруйнівного контролю в процесі буріння та проведення скускопідіймальних операцій. На основі вивчення процесу росту втомної тріщини можна розробляти заходи щодо зменшення напружень, які діють на бурильну колону, звести до мінімуму утворення промивин, що дозволить збільшити довговічність бурильних труб.

Ключові слова: бурильна труба, тріщина, коефіц̧ієнт інтенсивності напружень, кінетика, цฺикл навантаження, залишковий ресурс

\section{ПРОГНОЗИРОВАНИЕ ОСТАТОЧНОГО РЕСУРСА БУРИЛЬНЫХ ТРУБ ПО КИНЕТИКЕ УСТАЛОСТНЫХ ТРЕЩИН В ДОКРИТИЧЕСКИЙ ПЕРИОД}

\section{В. Тирлич, В. Мойсишин}

Цель. Определение закономерностей развития трещин коррозионной усталости в высокопрочных бурильных трубах.

Методика. На основе подходов механики разрушения материалов трещину охарактеризовано площадей, которая является интегральной характеристикой. Воспользовавшись методом эквивалентных площадей, вместо плоской усталостной трещины произвольной конфигурации рассмотрено эквивалентую ей по площади полукруговую усталостную трещину. Исследована кинетика ее роста на основе решения дифференциального уравнения первого порядка, которое определяет зависимость радиуса эквивалентного полукруга от числа циклов нагружения при заданных начальных условиях. Критический размер радиуса определен из условия того, что хотя бы в одной точке контура достигается условие перехода к нестабильному разрушению.

Результаты. Оценен остаточный ресурс бурильной трубы ТБПВ 127×9,19 S-135 с выявленной поперечной трещиной фиксированной площади, который при заданных режимах работы составил 653000 циклов, то есть 181 час. По промышленным данным эта труба отработала в скважине 3215 часов, в том числе 200 часов после последней дефектоскопии, что коррелирует с полученным результатом.

Научная новизна. Предложенная математическая модель развития усталостной трещины позволяет приближенно, с достаточной для практики точностью, рассчитывать остаточный ресурс бурильных труб.

Практическая значимость. Полученные закономерности могут быть использованы для отбраковки поврежденных труб, а также для обоснования проведения периодического неразрушающего контроля в процессе бурения и проведения спускоподъемных операций. На основе изучения процесса роста усталостной трещины можно разрабатывать меры по уменьшению напряжений, действующих на бурильную колонну, свести к минимуму образование промоин, что позволит увеличить долговечность бурильных труб.

Ключевые слова: бурильная труба, трещчина, коэффициент интенсивности напряжений, кинетика, иикл нагружение, остаточный ресурс

\section{ARTICLE INFO}

Received: 26 May 2019

Accepted: 7 September 2019

Available online: 17 September 2019

\section{ABOUT AUTHORS}

Volodymyr Tyrlych, Assistant Professor of the Higher Mathematics Department, Ivano-Frankivsk National Technical University of Oil and Gas, 15 Karpatska St, 76019, Ivano-Frankivsk, Ukraine. E-mail: turluch27@ukr.net

Vasyl Moisyshyn, Doctor of Technical Sciences, Professor of the Higher Mathematics Department, Ivano-Frankivsk National Technical University of Oil and Gas, 15 Karpatska St, 76019, Ivano-Frankivsk, Ukraine. E-mail: math@nung.edu.ua 